\title{
A CASE OF MYXEDEMATOUS PSYCHOSIS
}

\author{
CLINICAL AND PATHOLOGIC REPORT \\ S. UYEMATSU, M.D. \\ Pathologist and Assistant Physician, Danvers State Hospital
}

HATHORNE, MASS.

IN TRODUCTION

In 1873, Gull described five cases of a peculiar disease under the title "On a Cretinoid State, Supervening in Adult Women," and explained the similarity to sporadic cretinism, which was described by Hilton Fagge. In 1877, Orth reported five similar cases, and noticed especially the condition of the skin, in which he found an excess of mucin. $\mathrm{He}$, accordingly, named the disease myxedema. He found also, in a case that came to necropsy, atrophy of the thyroid gland, which was previously noticed by Curling in a case of sporadic cretinism.

An exact understanding of this condition, however, is dated from the time when Reverdin and Kocher recognized cachexia strumipriva, and when the same condition was brought out experimentally by removing the thyroid.

Semon is the first one who claimed definitely that myxedema, cachexia strumipriva, sporadic and endemic cretinism, are in the same disease group, and are characterized by the failure of the function of the thyroid.

Alcoholism, syphilis and numerous pregnancies, especially when accompanied with much loss of blood, have been thought to be the cause of myxedema. Kocher described a case in which myxedema was accompanied by gummatous syphilis of the thyroid, both being cured by iodin treatment. The same author observed another case in which actinomycosis was the cause of the disease; the patient was cured by incision and drainage. Sometimes myxedema is found in conjunction with goiter. These cases are reported by Murray, Heinzheimer, Gantier, Robertson, Imredy, Hischl, Ulreich and others. Among the most important causes of the disease are also acute infectious diseases, such as typhoid, malaria, acute rheumatism, pneumonia, etc.

Though the disease is found nearly everywhere, it is said to be more frequent in England, France and Switzerland. It occurs in cold climates rather than in the tropics, but it is not common in North America. 
Women are far more frequently afflicted than men. Prudden found 145 cases, 32 men and 113 women; Murray, 425 cases, 55 men and 370 women; Heinzheimer, 127 cases, 10 men and 117 women. The predisposition of women is probably due to frequent congestions and toxic infectious disturbances of the thyroid during menstruation, pregnancy, menopause, etc.

The most pronounced symptoms are myxedematous infiltration of the body, dryness of the skin, falling of the hair, slowness of the movements and certain nervous and mental symptoms. Sensory organs are often afflicted; hearing, taste and smell are diminished. Deafness is quite common, and it is thought to be of central origin. The extremities, lips and nose are cold and cyanotic, circulation is slow and the pulse rate varies from 50 to 65 . Cerebellar symptoms due to the disease were reported in 1910 and 1911 by Soederbergh. ${ }^{1}$ He observed cases with adiadokocinesis, Babinski's cerebellar catalepsy and exaggerated irritability of the muscles, but without symptoms of dementia.

The frequency of myxedematous psychosis is differently reported by various authors. Wagner and Jauregg ${ }^{2}$ gave a percentage of 15 . In the majority of cases the psychosis occurred late, after many years' duration, but in a few cases the psychosis occurred in the beginning of the disease, as reported by Pilcz, Inglish and Sierau.

The symptoms of the psychosis are not characteristic. Most patients seem to be demented, with more or less delusions, which are not infrequently based on hallucinations. The delusions are apt to be persecutory in character. The tendency to misbelieve is claimed to be one of the characteristics of the disease, and is an important factor in the development of the delusional conditions. Under the influences of persecutory ideas, patients are apt to become disturbed, cry, become agitated and sometimes extremely violent. In other cases there are reported several different symptoms, such as grandiose ideas, manic exaltations, or melancholia, anxiety and suicidal ideas. The latter cases are reported by Pilcz, Kraepelin, Show, Inglish, Beadles, Clouston, Hamilton, McLane and others.

The most important pathologic anatomical finding is that of the thyroid; even by palpation the organ shows remarkable atrophy. At necropsy it weighs one-tenth of the normal gland. Burghart observed

1. Söderbergh: Ueber Pseudotetanus myxoedematoides, Monatschr. f. Psychiat. u. Neurol. 32:402, 1912. Encore un cas de myxoedème avec symptômes cérébelleux, Rev. neurol. 19:86, 1911. Faut-il attribuer à une perturbation des fonctions cérébelleuses certains troubles moteurs du myxoedème, Rev. neurol, $2: 487,1910$.

2. Wagner and Jauregg: Myxoedema und Kretinismus, Handbuch der Psychiatrie, Aschaffenburg, 1912. 
a case in which he could not demonstrate any gland tissue. Some authors, such as Cunningham, Robinson, Corkhill, Schwass and others, have reported cases of enlarged thyroid in living patients. Microscopic examination shows marked increase of fibrous tissue. Some authors observed lymphocytic infiltration in the parenchyma in the early stage of the disease. According to Prudden, the parenchyma of the gland is more or less completely replaced by fibrous tissue and by newly formed reticular tissue in which are lymphocytes, resembling the tissue of the lymph nodes.

The majority of authors consider that the increase of the connective tissue is secondary, and that the primary cause is the atrophy of the gland tissue, which is probably due to some toxic agent. Ponfick believes in the possibility of a primary infection of the interstitial tissue which may give rise to secondary atrophy of the gland tissue.

The pituitary body is often found enlarged, as in the cases of Boyce and Beadles, Ponfick, Murray and others, but in one case Ponfick found atrophy of the gland. The relation of the pituitary body to myxedema still remains obscure.

No characteristic, regularly appearing findings have been reported in other organs of the body. The pathologic anatomy has given no satisfactory explanation for so marked disturbances in the mental and psychical realms. Brain, spinal cord and nerves are found either normal (Hun, Prudden, West and Harely), or the findings are not absolutely characteristic.

In about half of the cases atheroma of the aorta and large arteries has been found. Endarteritis of the small arteries is also one of the frequent findings.

In the Danvers State Hospital laboratory we have had two cases of myxedema in a total of 2,130 necropsies, beginning in 1879 and ending in the present year. The necropsy of the first case, a 45-yearold female, case number 15840 , was performed (Nov. 16, 1910) by Dr. A. H. Peabody. ${ }^{3}$ The clinical symptoms and pathologic findings correspond to those of a typical case. But, I regret to say, I could not study that case in connection with the present one, because the brain was not available and the description concerning the central nervous system is missing. Some of the clinical and pathologic symptoms, however, show striking similarity to the present case, and will be referred to later in the discussion. The second case is the present one, of which we have been able to make a thorough study and to report as a typical case of myxedema.

3. Peabody: An Histological Study of the Thyroid Gland in Mental Disease, with Special Reference to Chronic Thyroiditis, Danvers State Hospital Laboratory Papers, 1910. 


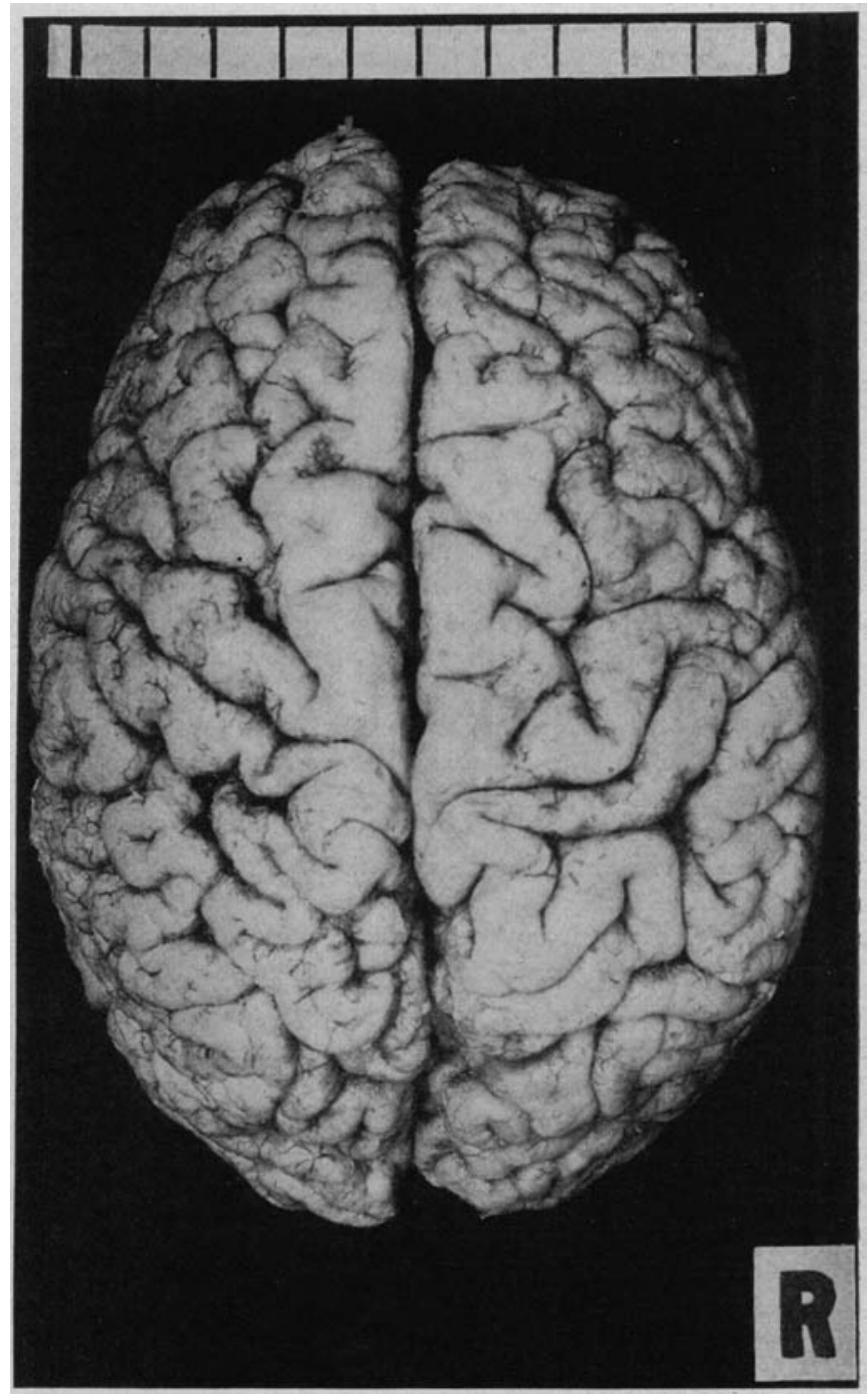

Fig. 1.-Superior surface of the brain. 


\section{REPORT OF A CASE}

CLINICAL OBSERVATION

History (Danvers State Hospital, Clinical No. 21477).-There was no history of nervous or mental diseases in the family, so far as was known.

The patient was born Jan. 1, 1853, in Nova Scotia. Early development showed nothing abnormal. She had very little education, and did not go to school until she was 9 or 10 years old, and then only for six months. She could barely read and write. She left home at 18 to do housework, and when about 20 married her cousin, by whom she had two children, one of whom died in infancy. Her husband died of typhoid and pneumonia two years after marriage, and shortly after that she came to the United States (about forty years ago), and did general housework. Thirty-eight years ago she married again, and had three children, one of whom died in infancy. The informant stated that the patient had some pelvic trouble ten years ago when about 55 years of age, and was operated on for two large broad ligament cysts on the right side; at the same time her appendix was removed.

Since that time she had been gradually failing, both mentally and physically. Her memory, especially for recent events, began to fail. She had had many attacks of vertigo, sometimes falling to the floor. These symptoms have gradually been growing worse, especially during the past year. About a year ago she was in danger of losing her home, and her son took her to his home and tried to keep her with him. She had always been very stubborn, self-willed and dictatorial, and insisted on having her own way. He could do nothing with her, and during the past year her daughter has been taking care of her. She became very untidy, and would wander about on the streets attired very carelessly. She persisted in going back to her own home. She would put things away, lose them, and then accuse her daughter of stealing them. At times she seemed depressed. She threatened to commit suicide, and on one occasion she tried to turn on the gas. Her daughter was afraid to leave her alone in the house. She would meddle with the cooking, and spoil the food by putting salt in it; she was dull and stupid, sleeping a good deal during the day. Her appetite was capricious; sometimes she ate an enormous amount. She was admitted to the Danvers State Hospital, March 24, 1919.

Physical Examination. - General: Her height was 4 feet 8 inches; her weight, 130 pounds. She was well developed and well nourished. The skin over her face and neck was pale yellowish and waxy. The musculature showed poor development, not much tone. Edema of the face, arms and legs was pronounced. The hair was grayish and very sparse; she was bald over the vertex. There was a linear scar extending from the umbilicus to the pubic bone.

Thoracic, Respiratory and Circulatory Organs: Results of the examination were negative except that respiration was slow, 14 per minute, and the pulse rate was only 60 per minute. The body temperature on admission was $98.8 \mathrm{~F}$.

Digestive and Abdominal Organs: Teeth were missing in the upper jaw, and a few stumps remained in the lower jaw. The breath was fetid. The tongue was extremely large and flabby and was slightly coated. The abdomen was large and pendulous.

Genito-Urinary Organs: No internal examination was made. The urine (March 27, 1919) was cloudy and straw colored. The specific gravity was 1.026. It was acid and showed a trace of albumin, mucous threads, epithelial cells, a few leukocytes and a few oxalate crystals, but no sugar. The Wassermann reaction on the blood serum was negative. 


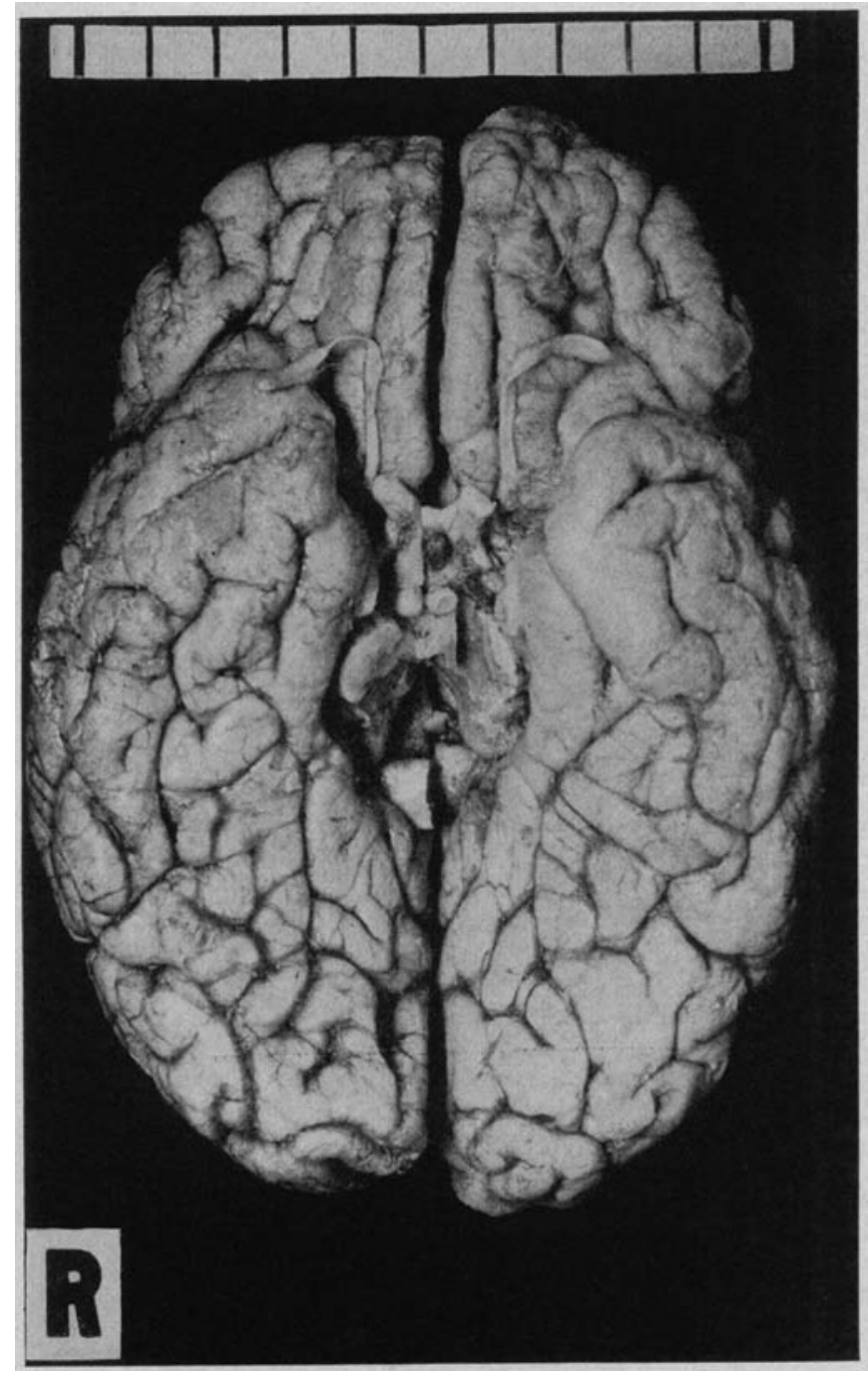

Fig. 2.-Inferior surface of the brain. 
Nervous System: General Sensations: She said that she had a feeling of weariness and exhaustion and wanted to sleep all the time. When she arose she was extremely dizzy and sometimes fell.

Eyes: The eyelids were so puffy that her eyes were almost invisible. She complained that her vision was poor; the pupils were unequal, the right being smaller, and they were very sluggish in responding to light.

Ears: She was totally deaf in the right ear, and could only hear when one shouted in the left ear.

Taste and Smell: These were apparently normal.

Cutaneous Sensibility: Tactile appreciation was somewhat impaired. She found it difficult to differentiate between pin prick and pencil. She was not always able to localize for time and space. She complained of numbness of the left arm and leg.

Deep Sensibility: There was no tenderness of the nerve trunk on pressure. The stereognostic sense was good.

Vasomotor Condition: There was an almost general edema, more pronounced in the face, hands and feet, and considerable abdominal ascites.

Reflexes: The knee jerks were sluggish, especially in the left knee. There was no ankle clonus. The organic reflexes were impaired.

Motor Functions: Motility of the facial muscles was poor, owing to the general edema. The tongue protruded in the median line. There was no tremor. The gait was unsteady. Coordination of movements was poor. She was unable to balance herself without assistance, and could not stand in the Romberg position. She had fallen several times, and said this was due to dizziness. She slept all night and the greater part of the day.

Mental Examination.-General Appearance and Attitude: Her face was so waxy and expressionless that with a little "touching up" her resemblance to a clown would be striking. She lay in bed in a sort of stupor most of the time.

Speech: Speech was thick, and she talked in a harsh, raucous voice.

Consciousness and Orientation: She was partially oriented. She knew that she was at Danvers, but was not oriented for time and person. She said it was 1993.

School Knowledge: This was very meager.

Calculation Ability: Her ability to calculate was very poor.

Hallucinations: She had had no hallucinations so far as could be ascertained, and there was no history of them.

Memory: Her memory for remote events was fairly good, but poor for recent events.

Judgment: It was impossible to elicit any definite delusions. She said she did not get along very well with her husband, but denied that it was her fault She said that everybody tried to boss her around, and she could not stand it any longer. She admitted that she was a little forgetful, but she could remember what happened twenty years ago as well as any one. She was lacking in insight.

Emotions: She was not at all emotional; in fact, she was dull and apathetic. She showed no apprehensiveness, and had not been irritable since she came to the hospital.

Social Relations: She was untidy in her habits, but otherwise caused very little trouble.

Course of the Disease.-March 27, 1919: Slept most of the time. Rather stupid; inordinate appetite.

April 4: She was stupid and sleepy; very deaf; disoriented; no delusions.

April 22: She failed gradually and died today. 


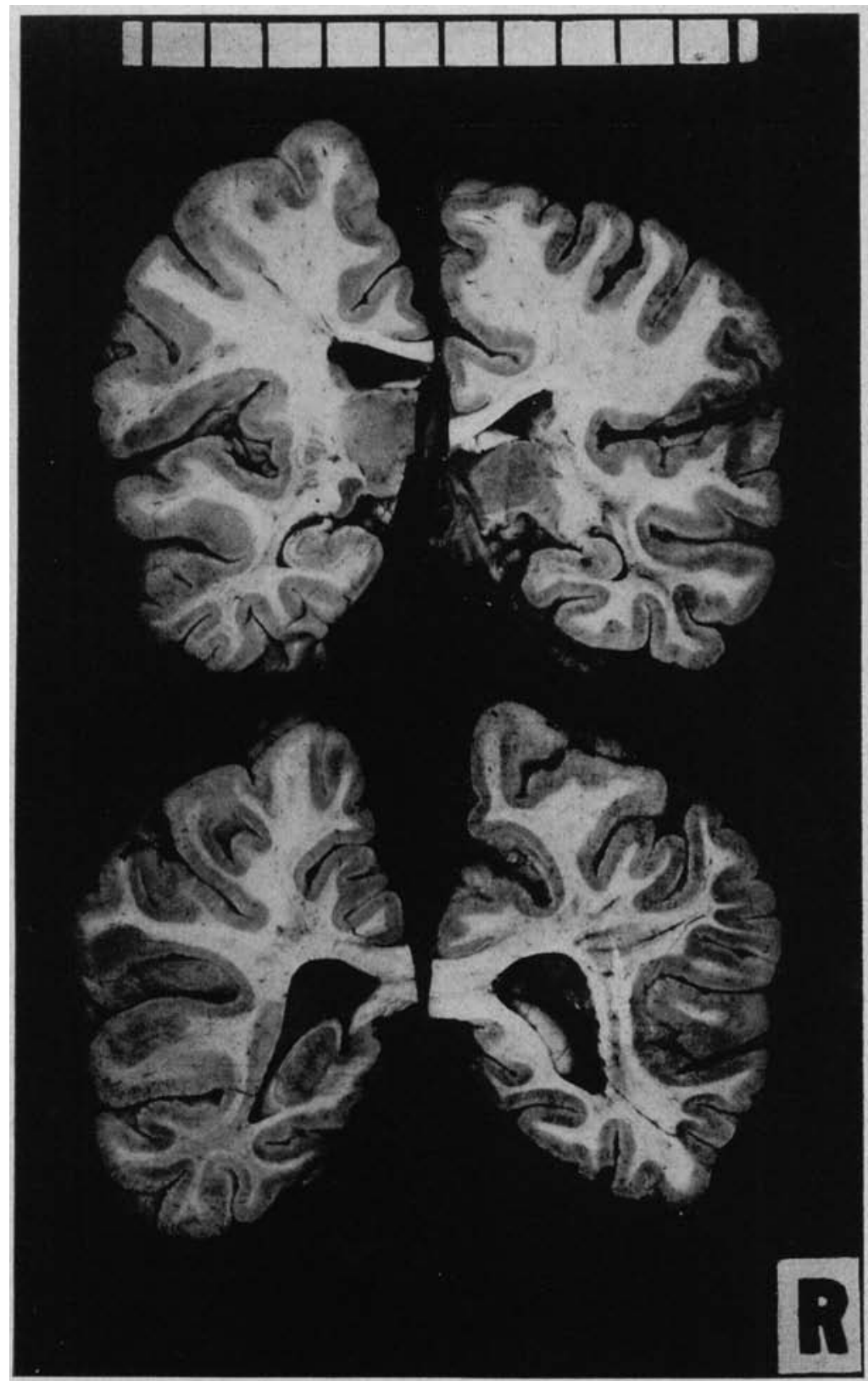

Fig. 3.-Cut surfaces of the brain. 


\section{POSTMORTEM EXAMINATION}

(Made twenty hours after death)

1. Gross Anatomy.-General Description: The body weighed $57 \mathrm{~kg}$; its length was $150 \mathrm{~cm}$. The body was that of a well developed and well nourished female, aged 66 , but apparently older. The skin over the face and neck was yellowish; other parts were grayish white. The face, chest, upper and lower extremities showed edema. There was rigor mortis. The hair was grayish and very sparse, and the head was bald over the vertex. The face was waxy and reminded one of a clown's face. The eyelids were swollen and edematous; the palpebral and orbital conjunctivae were edematous and injected; the pupils were slightly irregular; both measured $4 \mathrm{~mm}$. The nose was broad and swollen, but otherwise not remarkable. The teeth were poor; many were missing. The tongue was thick and coated. There was no discharge from the ears. There was a small nevus in the submental region. The thyroid was not palpable. The chest was well formed. The abdomen was flabby and pendulous. There was a scar extending from the umbilicus to the pubic bone. There were marked striae. There was an exostosis over the upper part of the right tibia. The lymph nodes were not palpable.

Ventral Section: The fat over the chest measured $1 \mathrm{~cm}$., over the abdomen, $2.6 \mathrm{~cm}$., and was very pale in color and of fluid-like consistency. The muscles were pale in color, and were also edematous. The omentum was folded back over the transverse colon, and was rich in fat. The stomach was markedly distended. The appendix was removed; also the right ovary. The uterus was in midline. There were no adhesions around the gallbladder. The spleen was free.

Thoracic Cavity: The mammary vessels stood open on section. The lungs did not meet and were retracted. There were no adhesions around the lungs. The pleural cavities contained free fluid. The pericardial sac was enormously distended, and contained an increased amount of straw-colored fluid.

Heart: It weighed $470 \mathrm{gm}$. and measured 12 by 13 by $6 \mathrm{~cm}$. The descending branch of the left coronary artery was remarkably sclerosed, and a part of it practically occluded by yellowish atheromatous softening. The measurements were: tricuspid valve, $11.5 \mathrm{~cm}$; pulmonary valve, $8 \mathrm{~cm}$; mitral valve, $9.5 \mathrm{~cm}$. The mitral valves were calcified and contracted. The ostium admitted more than three fingers. The aortic valve measured $7 \mathrm{~cm}$. The cusps were thickened. Origins of the coronaries were remarkably calcified. The left ventricle wall measured $2.2 \mathrm{~cm}$., the right ventricle wall, $0.6 \mathrm{~cm}$. The cardiac muscle was pale and soft.

Left Lung: The left lung weighed $400 \mathrm{gm}$. and measured 22 by 16 by 4 $\mathrm{cm}$. There was no apical scar. The anterior edge of the upper lobe was emphysematous. The surface of the lower lobe was grayish in color. The cut surface was dark red; dark colored blood oozed from the lung; there was no frothy fluid. Sections floated. The bronchial wall was injected and covered by hemorrhagic fibrinous exudation. The peribronchial lymph nodes were enlarged and pigmented.

Right Lung: It weighed $480 \mathrm{gm}$. and measured 21 by 18 by $5 \mathrm{~cm}$. The anterior border of the middle lobe was emphysematous. There were hardened areas in the lowest lobe. The cut surface showed an irregular, slightly elevated induration around the bronchi. The bronchial wall was markedly injected. On pressure, bloody, frothy fluid oozed from the lung. Sections floated. 
Liver: This organ weighed $1,4,30 \mathrm{gm}$., and measured 24 by 19 by $7 \mathrm{~cm}$. The capsule was thickened and slightly opaque. The surface was slightly granular. The color was partly greenish blue and partly reddish. The cut surface showed slight evidence of congestion and fatty change. The gallbladder contained small, sandy stones which were dark in color and crumbled easily. The wall of the gallbladder was injected.

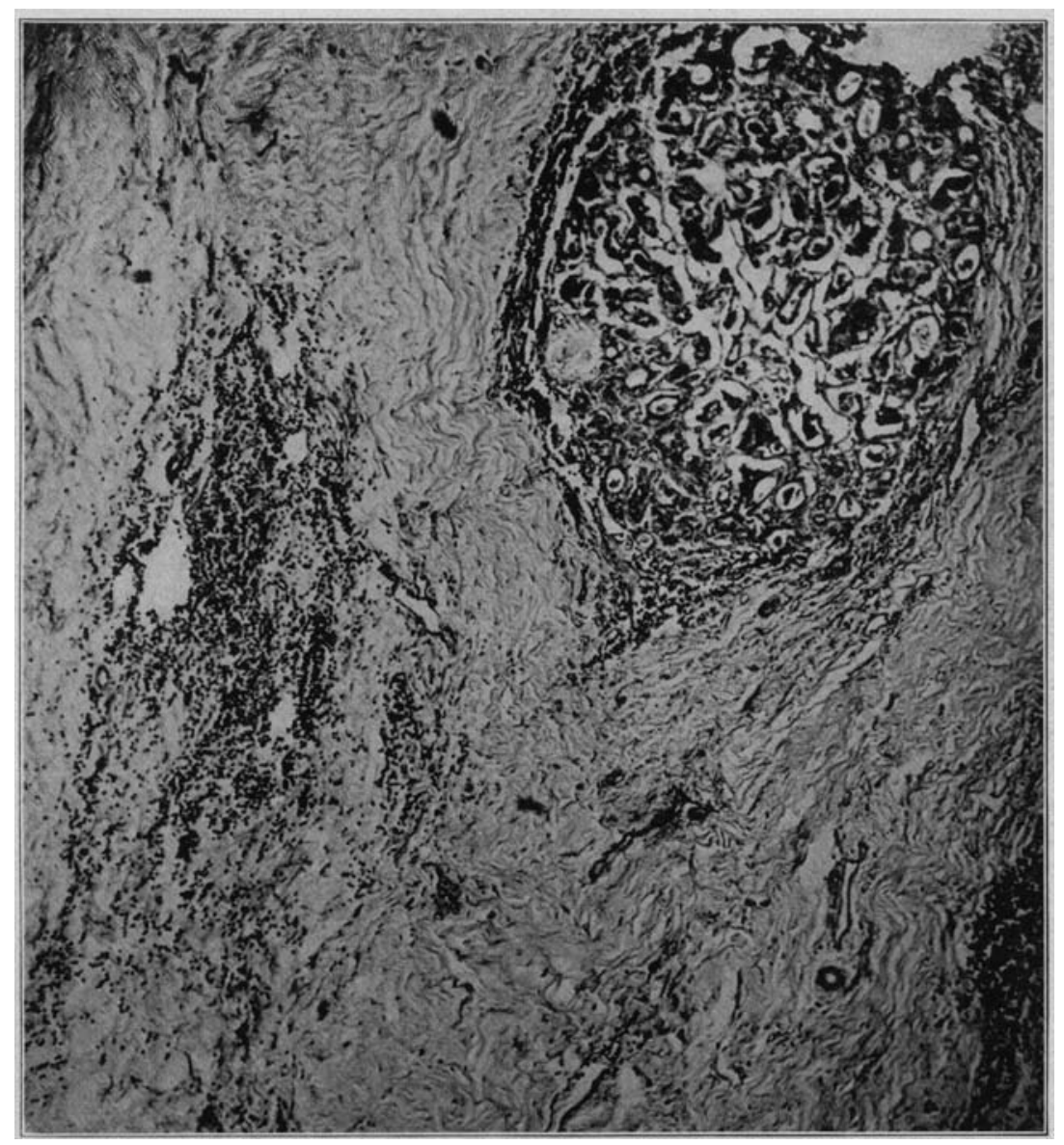

Fig. 4.-The thyroid gland, showing fibrosis and lymphatic cell infiltration. Hematoxylin-eosin staining.

Spleen: It weighed $170 \mathrm{gm}$, and measured 12 by 8 by $4 \mathrm{~cm}$. It was pear shaped. The capsule was thickened. The surface was granular and clouded. The organ was of unusually hard consistency and there were four fetal lobulations. The cut surface was dark red. The pulp did not bulge and was not easily scraped away. The malpighian bodies were hardly visille.

Left Kidney: This kidney weighed $110 \mathrm{gm}$. and measured 9.5 by 5 by 3.5 $\mathrm{cm}$. The fatty capsule was increased. The fibrous capsule stripped with some difficulty. The surface of the organ was markedly granular. There were many 
small cortical cysts. The cut surface was pale in color. The cortex measured $0.4 \mathrm{~cm}$. The pyramids were not well defined and there were whitish striations in the pyramids which suggested increased interstitial tissue. The pelvic fat was remarkably increased.

Right Kidney: The right kidney weighed $110 \mathrm{gm}$. and measured 10 by 6.5 by $3 \mathrm{~cm}$., otherwise the description was the same as for the other kidney.

Suprarenals: The cut surface showed some increased yellow deposits.

Thyroid: The thyroid was very small; it weighed $10 \mathrm{gm}$. Careful dissection revealed no isthmus. The cut surface showed no proper structure of the thyroid gland. It appeared to be represented by some fatty and more fibrous tissue. It was fairly firm in consistency.

Parathyroid: The parathyroid glands could not be identified.

Genito-Urinary Tract: The bladder was contracted and contained no fluid. The mucous surface was not remarkable. The vagina was smooth. There were small hemorrhagic areas. The uterus contained turbid fluid; the wall was hemorrhagic and firm in consistency. Section showed abundance of vessels and increase of fibrous tissue. The right ovary was absent, and the broad ligament was adherent to the stump of removed appendix; the left ovary was smaller than normal. The surface was greatly roughened and firm in consistency. Cut surface showed dilated vessels and small cysts.

Gastro-Intestinal Tract: The stomach was distended and contained a greenish mucoid fluid. Mucous membrane was injected. The intestines contained a chocolate colored fluid. The intestinal walls showed a bluish green discoloration, probably of postmortem change. The colon and rectum were not remarkable.

Pancreas: Nothing remarkable was found in the pancreas.

Head: The scalp was thick and adherent to a dense calvarium. There was no diploe. The calvarium was somewhat thickened. The grooves for the middle meningeal arteries were not deep.

Brain: The brain weighed $1,000 \mathrm{gm}$. The dura mater was thickened. The pia mater was irregularly thickened and showed milky cloudiness over the vertex. The brain was soft and edematous. Superior surface of the brain: There was congestion of the veins, especially on the left side. The pia mater was adherent everywhere over the lateral surface of both hemispheres. A large part of the right posterior central convolution was remarkably narrow. Convolutions of the right cuneus, especially bordering on the margin of the hemisphere, appear much atrophied. The posterior part of the right lingular gyrus was markedly sunken from the surface. The upper part of the left posterior central convolution and left superior parietal convolution was much narrower than normal. The angular gyrus of the left side was also atrophic. Base of the brain: The cranial nerves were not remarkable. The basilar artery and internal carotids were remarkably sclerotic. The pons appeared smaller than normal and resistant to the touch.

Cut surfaces of the brain (Meynert's section): Nothing remarkable was found, except that the above mentioned atrophic convolutions appeared also atrophic on section.

Pituitary Body: This was slightly smaller than normal and was firm in consistency.

Internal Ears: Nothing of note was found in regard to the internal ears.

Spinal Cord: Nothing remarkable was found in the spinal cord.

Anatomic Diagnosis: The body was well developed and well nourished, and there was myxedema of the entire body. The fingers were cyanosed. The 
conditions noted included alopecia, a waxy clown-like face, irregular pupils, poor teeth, thick tongue, operation scar on the abdomen, exostosis over the upper part of the right tibia, myxedematous condition of the muscle and fatty tissues, ascites, the appendix and the right ovary missing (by operation). There were also hydrothorax, hydropericardium, dilatation and hypertrophy of the heart, arteriosclerosis of the aorta, major arteries of the body and coronaries; also basilar and cerebral arteriosclerosis; increased pericardial

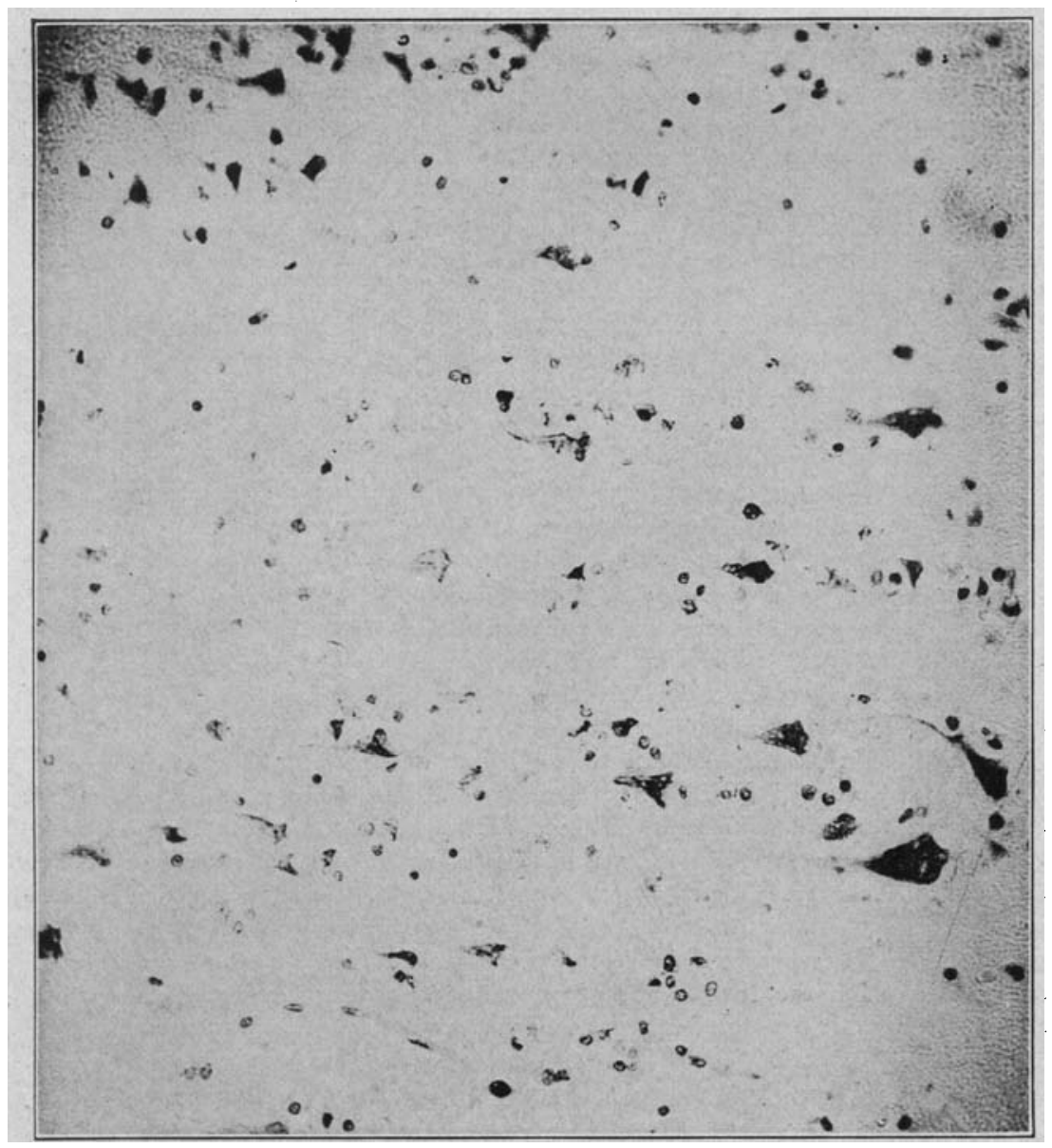

Fig. 5.-Cell sclerosis with fatty degeneration, cells of third layer, superior frontal convolution. Thionin staining.

fat, emphysema of the lungs, hemorrhagic fibrinous bronchitis, bronchopneumonia of the right lower lobe, congestion and fatty change of the liver, cholelithiasis, a large spleen with increased trabeculation, fatty and fibrous replacement of the thyroid, chronic endometritis and eburnation of the calvarium. Diploe was absent. The brain was small; weighing $1,000 \mathrm{gm}$. There were chronic pachymeningitis, chronic leptomeningitis and irregular atrophy of the convolutions. 
2. Microscopic Anatomy.-(a) General Histologic: Thyroid: This was almost completely replaced by fibrous tissue. The ordinary tissue was extremely atrophied, appearing here and there like tiny islands. The thyroid contained practically no colloid matter. The remaining gland tissue was infiltrated and surrounded by small spheroidal or lymphatic cells. In some parts the small lymphatic cells occupied the place of the gland tissue and gave the appearance of the normal lymphatic tissue of the lymph nodes. The small arteries, both in the newly formed lymphatic tissue and in the connective tissue, were remarkably thickened, but showed no perivascular infiltration.

Pituitary Body: The anterior lobe was somewhat smaller than normal and the posterior lobe was remarkably small. The cells of the anterior lobe appeared rather numerous and compact, and the acidophilic cells had increased in the central part as well as in the periphery. The intermediate part extended further into the posterior lobe, but showed no evidence of secretion of colloidal matter. There was slight thickening of the walls of the vessels, and they were infiltrated by lymphocytes, differing in this respect from the vessel picture in the thyroid.

Uterine Wall: There was a formation of a thick layer of newly formed, very vascular tissue over the surface of the mucous membrane.

Ovary: There was a formation of dense new interstitial connective tissue around the walls of the arteries and the surface of the organs. The veins were dilated. Here and there obliterating endarteritis appeared.

Adrenals: These showed a moderate grade of fatty degeneration.

Pancreas: Nothing remarkable was found in the pancreas.

Spleen: Chronic indurative splenitis with abnormally increased pigmentation (hemosiderin) in the cells of the pulp was found.

Lung: The right lower lobe showed exudative pneumonia about the bronchial tubes forming the lobular areas.

Heart: There was brown atrophy of the cardiac muscle with areas of scar formation.

Liver: Chronic congestion and fatty change were found.

(b) Microscopical Findings of the Brain: Pieces were taken from the superior frontal, anterior and posterior central, Heschl's transverse and superior parietal convolutions of both hemispheres; also calcarine region, cornu ammonis and several other parts appearing atrophic by macroscopic observation. These pieces were cut by frozen section and by embedding in paraffin, the latter for the purpose of staining by thionin, hematoxylin-eosin, Van Gieson and glia method, the former for fat staining, modified Weigert-Pal's staining and Bielschowsky's silver impregnation.

Hematoxylin-Eosin and Van Gieson's Method: The pia mater was irregularly thickened, especially over parts of convolutions which appeared atrophic. The vessels of the pia mater and upper cortex layer showed marked arteriosclerotic alterations. The thickened parts of the pia mater and the cortex underneath, which often had sunk from the surface, contained numerous amyloid corpuscles. Here and there walls of vessels were calcified. Small vessels appeared to be much increased, disturbing the cell order of the cortex. The width of the cortex was irregular. In highly atrophic parts, such as those mentioned above, and in the neighborhood of the thickened vessels coming down from pia mater, the ganglion cells of the cortex had entirely disappeared, glia cells and glia fibers occupying such areas. The vessels in the deeper layer of the cortex and in the white matter were also thickened and showed marked perivascular gliosis. 
Thionin Staining: There was marked disorder of the cells in the superficial cell layers, especially in those of the frontal, anterior central and posterior central convolutions of both sides, right cuneus, posterior part of the right lingular convolution and left angular gyrus. In the deeper parts of the cortex the cell order was fairly regular, although there was some deviation of apical dendrites and some slight disarrangement of the cells. This condition suggested that the cortex layers supplied by short pial vessels had suffered more than the deeper cell layers which were nourished by medullary branches.

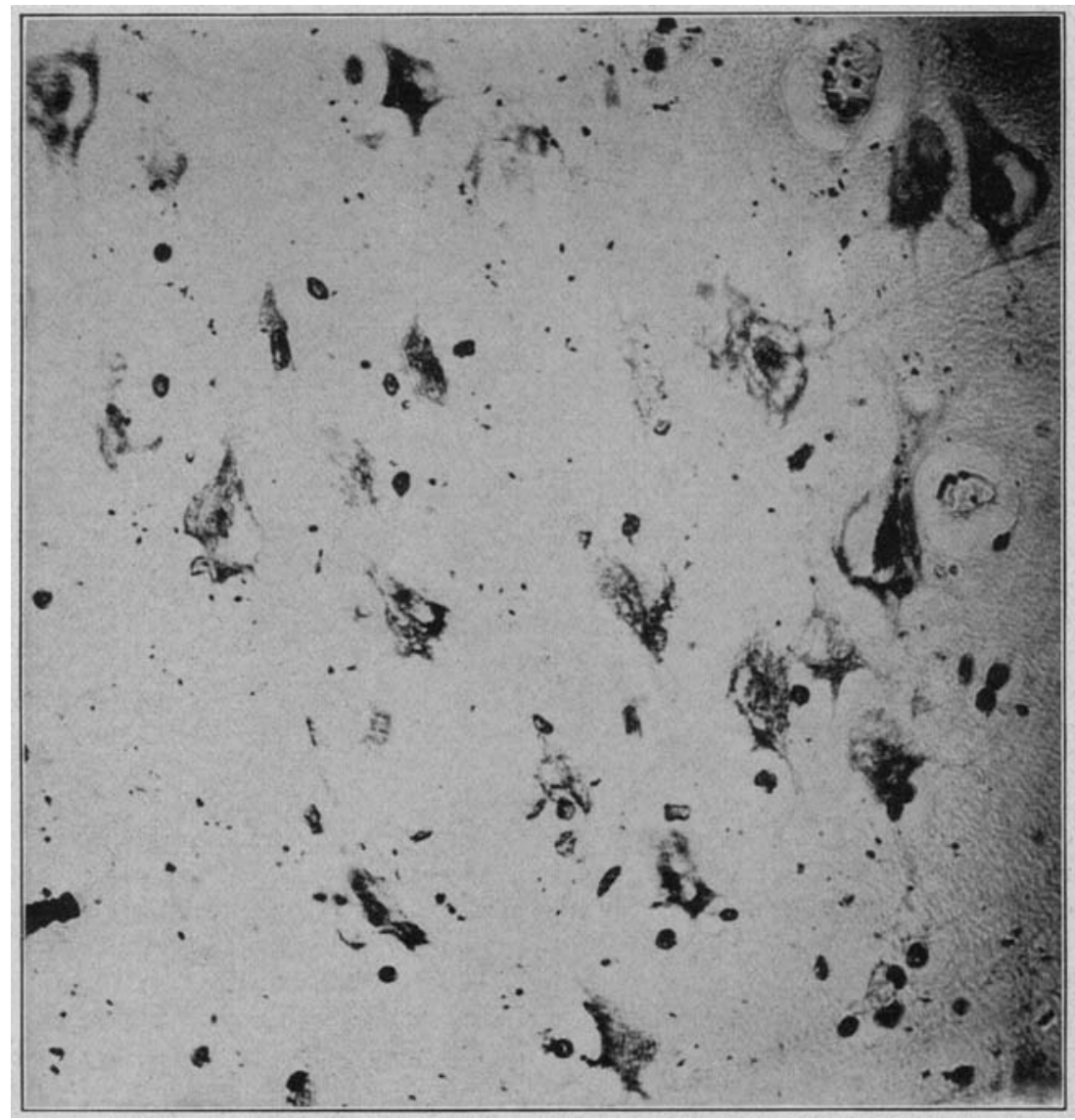

Fig. 6.-Ganglion cells of cornu ammonis showing cell change associated with edematous condition of the brain. Thionin staining.

The cell changes can be divided roughly into three different groups:

1. Cell Sclerosis (Nissl') Combined with Fatty Degeneration (Fig. 5).-This change was found in almost all of the cells of the second and third layers

4. Nissl: Der gegenwärtige staud du Nervenzellenanatomie und Pathologie, Allg. Ztschr. f. Psychiat. 51:981, 1894-1895. 
(Broadmann) and the majority of the deeper layers. These sclerotic cells showed dark stained nuclei often of elongated, pyramidal or polygonal shape. The protoplasmic body was also darkly stained and remarkably shrunken, making the border between protoplasm and nucleus obscure. The apical dendrites were well stained and traceable to a greater distance than in normal cells. Most of the apical dendrites of the second and third layers took a winding course. These sclerotic cells carried on their side or on their base protoplasmic reticulum which contained greenish and yellowish looking lipoid masses. A few of the apical dendrites contained also a lypoid mass and appeared to be swollen. This fatty sclerotic degeneration was found more markedly in atrophic parts of the cortex than in other places.

2. Fatty Degeneration with Gramular or Heavy Degeneration.-The cells of the deeper layers (Figs. 5 and 6) and the large cells of the third layer contained a remarkably large amount of fatty pigment. The protoplasmic reticulum containing fatty pigment was located either on the base, the side of the cell or over the apex. The nuclei of these cells were stained a little deeper than normal showing a wheel-like structure or a nebulous, less distinct structure around the nucleus. The nucleus was located eccentrically, owing to the pressure of the deposited fatty substance. It was irregular in most of the cells. The membrane of the nucleus was more or less preserved. Nissl's granules in these celis were either in good condition, finely granulated or had disappeared. Betz' cells, the large cells of the post central region, superior temporal convolutions and calcarine region showed a fairly good condition of Nissl's bodies. In the cells of the other parts granular degeneration predominated or the cells showed dark stained protoplasm with a net-like structure in it.

3. Cell Change Associated with the Edematous Condition of the Brain (Fig. 6).-This kind of cell change is found both in the superficial and in the deeper layers, combined with other cell degenerations. Nissl is the first author who gave attention to this condition of the cells. The protoplasmic part was torn apart from the nucleus or from the protoplasm around the nucleus. In some cells a crevice was observed across the width of the protoplasm or a vacuole-like cavity in several parts of the cell, some in the base or sides, others in the apex or even in the apical prolongation. The cavities were irregular in shape and appeared to be made by pulling apart a portion of the cell. At first these cavities were thought to be the remains of fat globules which had been dissolved by alcohol, but it was found that the same cavities were present in formaldehyde fixed specimens stained with scarlet red without the use of fat solvents. In the cornu ammonis the same condition of cavity formation was found around the nucleus showing a wide space between the protoplasm and nucleus. This kind of cell change is said to occur in cases in which the brain is found to be soft and edematous at necropsy. It is possible to cause this kind of cell change by the use of the reagents which withdraw water instantly from the brain tissue. Simchowicz says: "These cell changes are artefact to a certain extent, inasmuch as they are caused by fixing, but they may also be considered pathological, as their formation under fixation is the result of a definite pathologic condition, i. e., an edema of the brain."

5. Simchowicz: Histologische Studien über die senile Demenz, Histologische und histopathologische Arbeiten über de Grosshirninde, Nissl, 1911. 
In our cases the lorain was taken ont twenty hours postmortem. Before fixing in formaldehyde it was soft and edematous. We could not, of course, he sure how great a role the postmortem change played in this condition. The body, however. was kept cold $(25-30 \mathrm{~F}$.) and the weather at the time was very cool, and other brains coming to necropsy under the same conditions showed no such change. Moreover, the skin, fatty tissue and the muscles

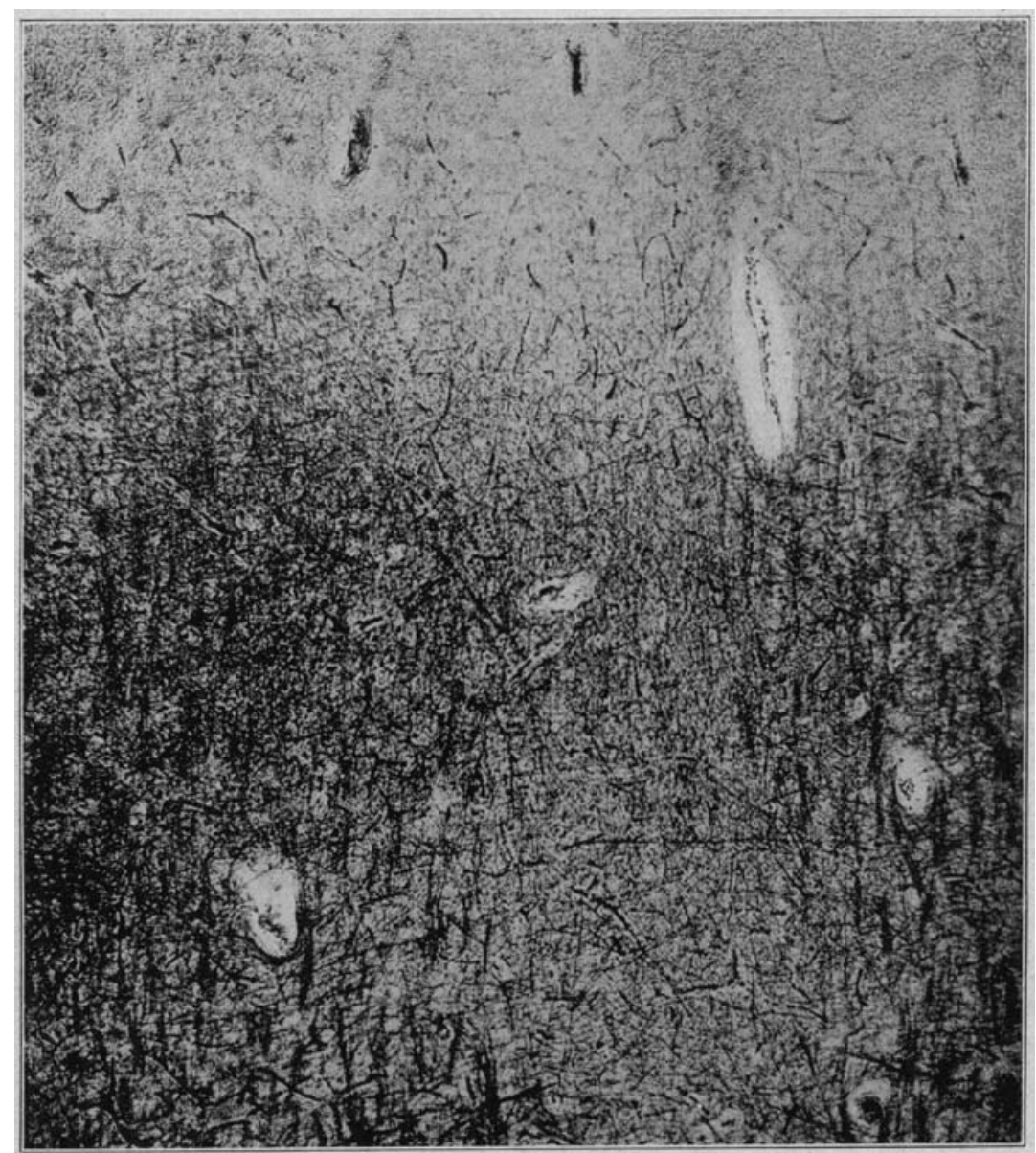

Fig. 7.-Degeneration of tangential fihers and supratadiate cross striations. Weigert-Pal myelin sheath staining.

showed edematous condition due to the disease. There is no reason, therefore, why the edematous condition of the hrain should be exempted from the pathologic change due to the myxedematous condition. Admitting that this cell change is partly artefact, caused by fixing solution, it must still be regarded as pathologic because of the borly disease and the condition of the brain, which gives rise to this change. 
Bielschowsky's Staining: This staining showed very plainly the alterations of small vessels, especially the so-called arterio-fibrosis of Friedmann, which Simchowicz and Fuller ${ }^{8}$ have illustrated in their papers and called attention to as one of the essential findings of senile changes. The arteriofibrosis was found more markedly in vessels of the upper cortex layers. Degeneration of the cortex beneath the pial covering and the scar formation around the arteriosclerotic vessels were observed. Sclerotic cells with fatty degeneration as compared with Nissl's staining showed dark stained protoplasm and nuclei with elongated apical dendrites. Intracellular and extracellular neurofibrils showed segmentation. Larger cells of the deeper cortex layer possessed pale stained nuclei and fairly well preserved intracellular neurofibrils. Fatty degeneration and cell changes caused by the edematous condition of the brain tissue were also observed.

Scarlet Red Staining: Fairly abundant fat corpuscle cells were found in thickened parts of the pia mater. The wails of the vessels of the pia mater and of the brain showed fatty degeneration. Fat corpuscle cells were found around the vessels and the highly degenerated cortex parts. Fatty degeneration of the ganglion cells is one of the most striking features of this case. All cells of the upper and the deeper cortex layers showed a deposit of an extremely large amount of fatty pigment substance. This condition existed over the entire brain tissue, while in the degenerated cortex and in the cornu ammonis it was perhaps most prominent. Spider cells of the surface layer and the large pale stained nucleus of the glia cells showed marked fatty degeneration.

Myelin Sheath Staining (Fig. 7): Tangential fibers were to a marked degree destroyed, here and there showing the remains of fine fibers and some hypertrophic ones. In the highly degenerated cortex the myelin sheaths are lost. Supraradiate cross striations (Supraradiaere Flechtwerke) were scarce. In the white matter there were degenerations running longitudinally with the vessels.

Glia: The glia cells were increased, especially in the deeper parts of the cortex and the white matter. Small dark stained nuclei were not so numerous as pale stained, larger forms with large nuclei which were often stained metachromatically. Around these were often observed (by thionin staining) yellowish and greenish appearing lipoid granules which stained markedly with sudan or scarlet red. This condition of lipoid accumulation around the nuclei was seen more distinctly in the cortex than in the white matter. In the neighborhood of the vessels of the white matter and the cortex, glia cells were remarkably increased.

Weigert's Glia Staining (Fig. 8): The surface glia layer was distinctly broader than normal, some of the fibers reaching deep into the cortex. The glia fibers were also increased remarkably in the atrophic parts of the cortex and around the thickened vessels. On the cortex surface where the atrophic parts had sunk from the normal level, the glia fibers were denser and penetrated deeper into the cortex. The whole feature of this picture of increased glia fibers is like a wedge form. The glia fibers consisted of a small number of thick fibers and a large number of finer and delicate ones. There were also areas in which glia fibers were growing into the pia mater, deep into the pial tissue. Corpora amylacea were very abundant in the atrophic parts of the cortex and the pia mater, where the glia fiber proliferation was most prominent.

6. Fuller: Further Observations on Alzheimer's Disease, Proceedings of the American Medico-Psychological Association, Sixty-Eighth Annual Meeting, 1912. 
(c) Microscopic Examination of the Cerebellum: Scarlet Red Staining for Fatty Degeneration: Purkinje cells stained diffuse brownish, showed no fat corpuscles or granules. Dendrites were not visible. There was a small number of fat corpuscle cells in the Purkinje cell layer. Walls of capillaries and arteries showed fatty degeneration and a small number of fat corpuscle cells were seen around them. There were a few corpora amylacea in the deeper part of the molecular layer and Purkinje cell layer.

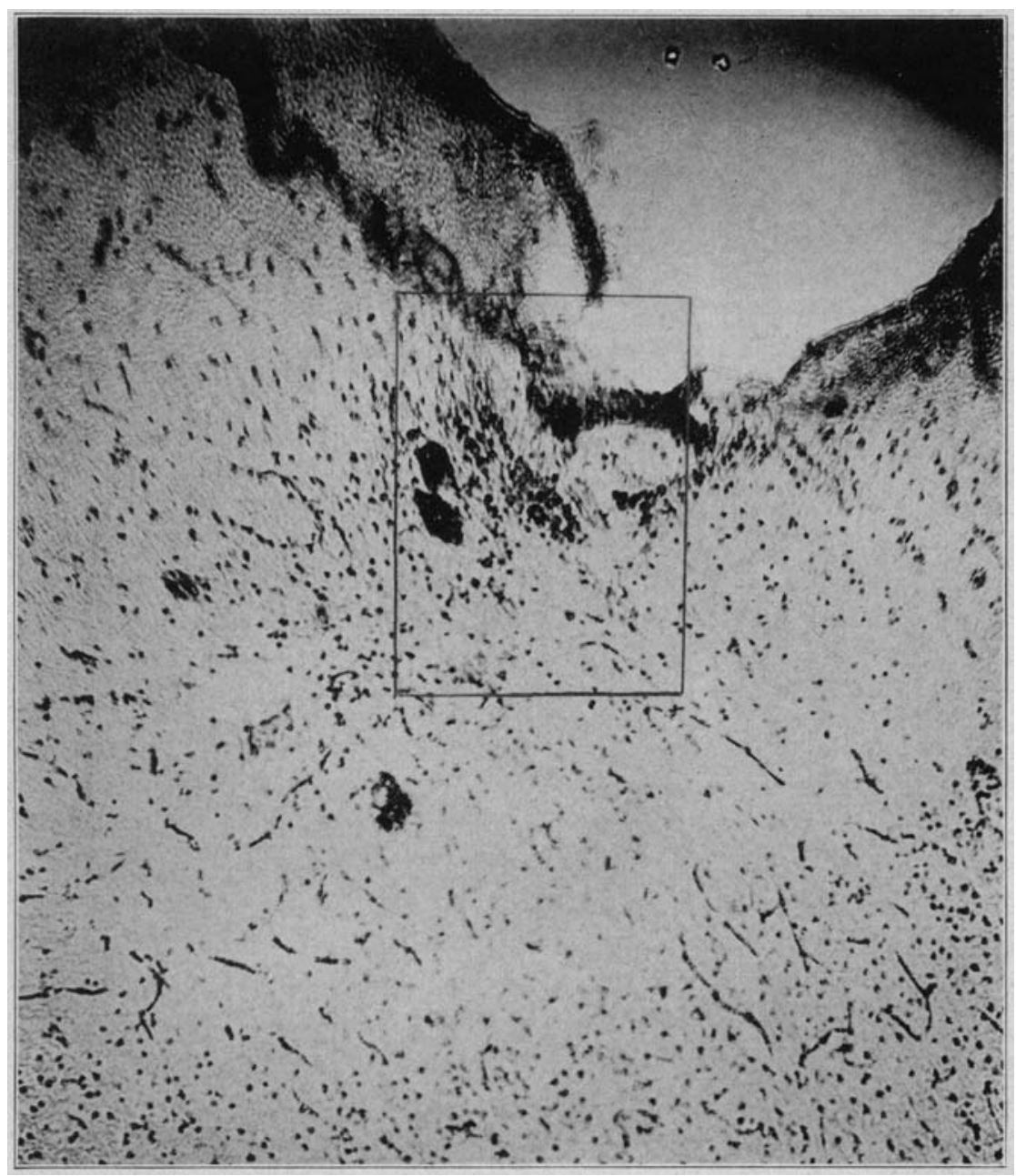

Fig. 8.-Thickening of the surface glia layer, thickening of the walls of vessels, luxuriant growth of the glia fibers and accumulation of amyloid corpuscles. Weigert's glia staining.

Bielschowsky's Staining for Neurofibrils (Fig. 5): The molecular layer was reduced in width. The cells in this layer, both those in the upper part and those in the deeper zone, were remarkably decreased. Tangential fibers showerl 
also diminution and they took a wavy course. The Purkinje cells were markedly destroyed, and those remaining appeared smaller and poorly stained, though an epicellular and endocellular network existed. Dendrites were for the most part absent, so that the molecular layer appeared much lighter; basket fibers and cushion fibers were diminished. The granular layer also appeared paler on account of the scarcity of the small spheroidal ganglion cells. Remarkably swollen fibers, whose origin was hardly determined, were found both in the molecular and granular layers. They might be either basket fibers, afferent fibers or nerve prolongations of Cajal's cells of the granular layer.

Some of the axis cylinders were swollen (not far from the Purkinje cells) to a peculiar shape, spindle, spheric, sac form or other shape. Neurofibrils in this swollen body appeared mostly homogeneous, taking diffusely silver stain. This latter finding is the same as that described and explained first by Cajal and later by Rossi, Marinesco ${ }^{7}$ and Schaffer. ${ }^{8}$ These authors found this peculiar local swelling of axis cylinders in some special diseases, and claimed that they were the result of a regenerative process of the axis cylinder, the continuity of which is disturbed. I have seen this peculiar swelling of the axis cylinder in several kinds of brain disease, and I am rather of the opinion that this is a kind of regenerative-degenerative process, seen in many kinds of diseases in which there is degeneration of the Purkinje cells. Accurate description and explanation of this change is not the purpose of this paper, but will be given in a later communication. The vessels appeared to be very much increased in number in all the cortex layers and in the white matter of the cerebellum. Each capillary showed marked arteriofibrosis, probably more marked than in the cerebrum.

(d) Microscopic Examination of the Spinal Cord: Little of note was found with the exception of a slight degree of arteriosclerosis and fatty degeneration of the cells of the anterior horn.

\section{THE AUTHOR'S CASE COMPARED WITH CASES IN LITERATURE}

The onset of the myxedema in this case is unknown. It appears to have begun ten years ago when the patient was operated on for broad ligament cysts. Since that time the patient had been slowly but progressively failing, both mentally and physically. Her memory had begun to fail, especially for recent events. She had had many attacks of vertigo, sometimes falling to the floor, and this condition had become much more conspicuous in the later stages of the disease; she could not stand in the Romberg position, her gait became unsteady. and she showed marked disturbances of coordination movements. The latter symptoms remind one of the cerebellar symptoms of the myxedematous patient, which has been reported by Soderbergh, though accurate examination for these symptoms was not made in the present case. In recent years she had become untidy and would wander about on the streets. At times she became depressed and threatened suicide.

7. Marinesco: Nouvelles contributions à l'étude de la régénérescence des filrres du système nerveux central, Jour. f. Neurol. u. Psychol. No. 17, 116, 1910.

8. Schaffer: Zum normalen und pathologischen Fibrillenbau der Kleinhirnrinde, Allg. Ztschr. f. d. ges Neurol. u. Psychiat. 21:1, 1914. 
Cases like this have also been described by Pilcz and others. Later, before and after her admission to the hospital, she became very dull and stupid, sleeping all the time.

The physical symptoms were typical. There was edema over the whole body. Bald head, "clown-like" face, thick flabby tongue, poor condition of the teeth, deafness, hydrops of the serous cavities. cyanosis of the hands, diminished activity of the reflexes. arteriosclerosis, bradycardia, etc.. all correspond to the typical case.

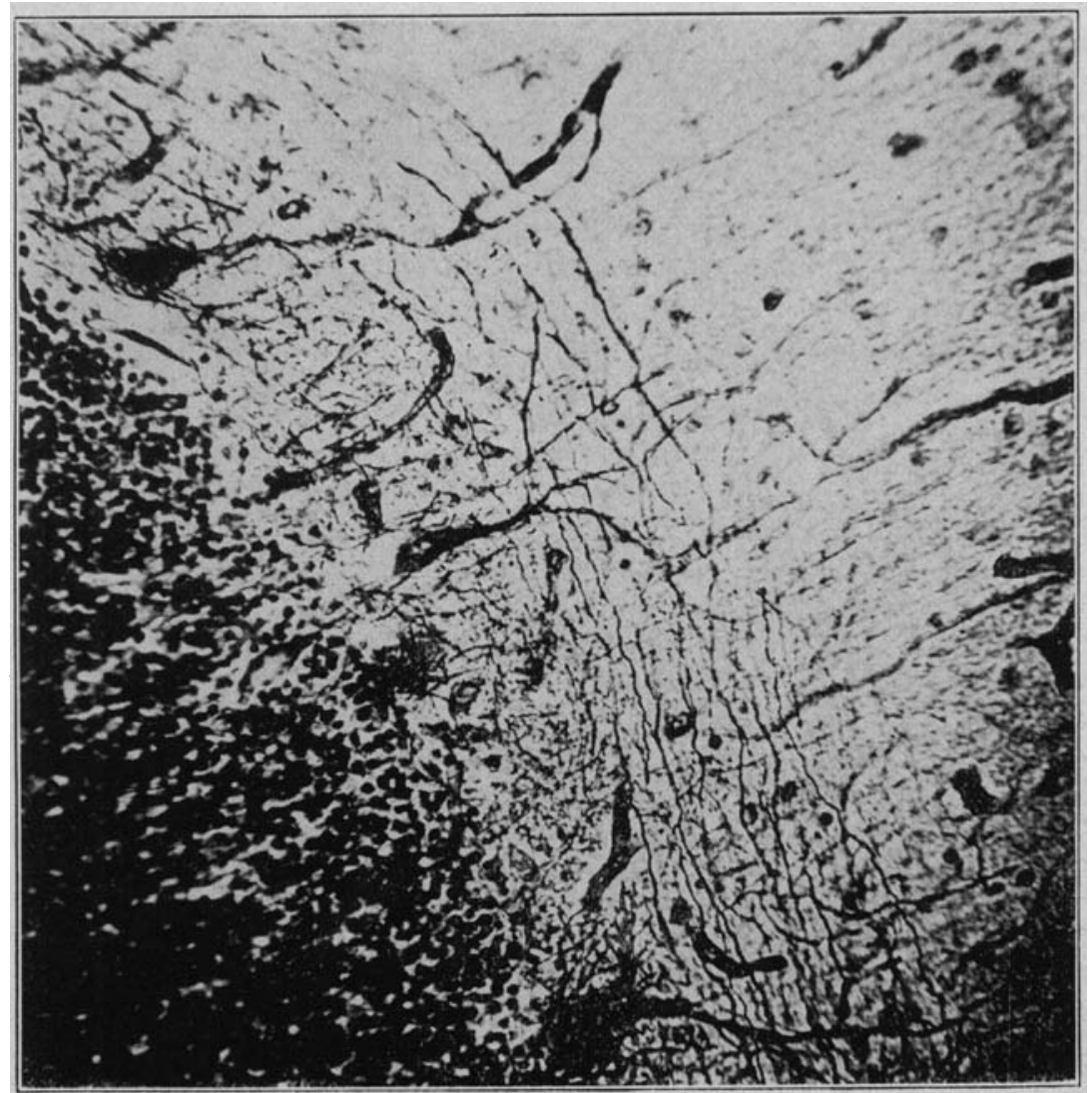

Fig. 9.-Swelling of the axis cylinder of the Purkinje cell (middle), emaciated cell body of the same cell. Bielschowsky silver impregnation method.

Gross anatomy showed an extremely atrophic thyroid gland, both sides equally small, and with no isthmus. In our first case in the Danvers State Hospital series, according to the description of Dr. Peabody, the thyroid consisted of two small, tough, fibrous masses not connected by any isthmus, lying one on either side of the cricoid cartilage and beginning trachea. On section it looked like pale fatty tissue with 
much connective tissue. The parathyroid in that case, as well as in the present case, could not be identified. Although the absence of the isthmus is not uncommon, it certainly is not typical. It makes me doubt, therefore, whether there is any relationship between congenital malformation and this disease.

Necropsy revealed the oöphorectomy of the right side and the appendicectomy. It is very interesting to have found the same condition in our former case about which the necropsy protocol says: "Appendix is absent. No tube and ovary on the right. The left tube is invisible in the mass of adhesions. The left ovary is small (residual). and there are thick fibrous adhesions between the ovary and the adjoining tissues and to the ileum." This fact, found both in our former and present cases, suggests to me a probable etiologic relationship between the pathologic condition of ovaries and the myxedema.

Microscopic examination revealed extreme atrophy of the thyroid gland replaced by fibrous tissue and infiltrated by lymphatic cells. The pituitary body was a little smaller than normal, contrary to the statements of authors such as Boyce and Beadles, Ponfick and Murray, who found enlargement of the pituitary body in this disease. Arteriosclerosis of remarkable degree was found in all vessels of the body and the brain. In our former case there was also marked arteriosclerosis throughout the aorta.

As for the brain, cerebellum and spinal cord, we found more or less remarkable pathologic changes differing from the description of some authors such as Hun, Prudden, West and Harely. But are these pathologic findings specific or characteristic of this disease? This is an important question.

Before answering this question, let us survey the nature of these pathologic changes. They can be divided into two groups, the one being more or less localized and the other general in character. The first group is expressed by localized degeneration in certain convolutions, degenerations around the sclerotic vessels of the superficial cortex layers, perivascular gliosis, perivascular and focal accumulation of fat corpuscle cells, destruction of myelin sheaths, proliferation of glia fibers in degenerated parts, irregular thickening of the pia mater and the surface glia layer, etc. Vessels of the pia mater and the superficial cortex layers showed more marked sclerosis than those in deeper layers. The same condition obtained in the arteriofibrosis of small vessels. This group of changes, however, is nothing but the arteriosclerotic alteration of the brain. The second group consists of universal changes, such as fatty degeneration with granular and heavy change ( Nissl), cell sclerosis with fatty degeneration, and the cell 
vacuoles associated with the edematous condition of the brain. Though the fatty degeneration and cell sclerosis are found in the arteriosclerotic nature of the alteration, they are not universally distributed over the whole of the brain. According to Simchowicz, "Pathologically

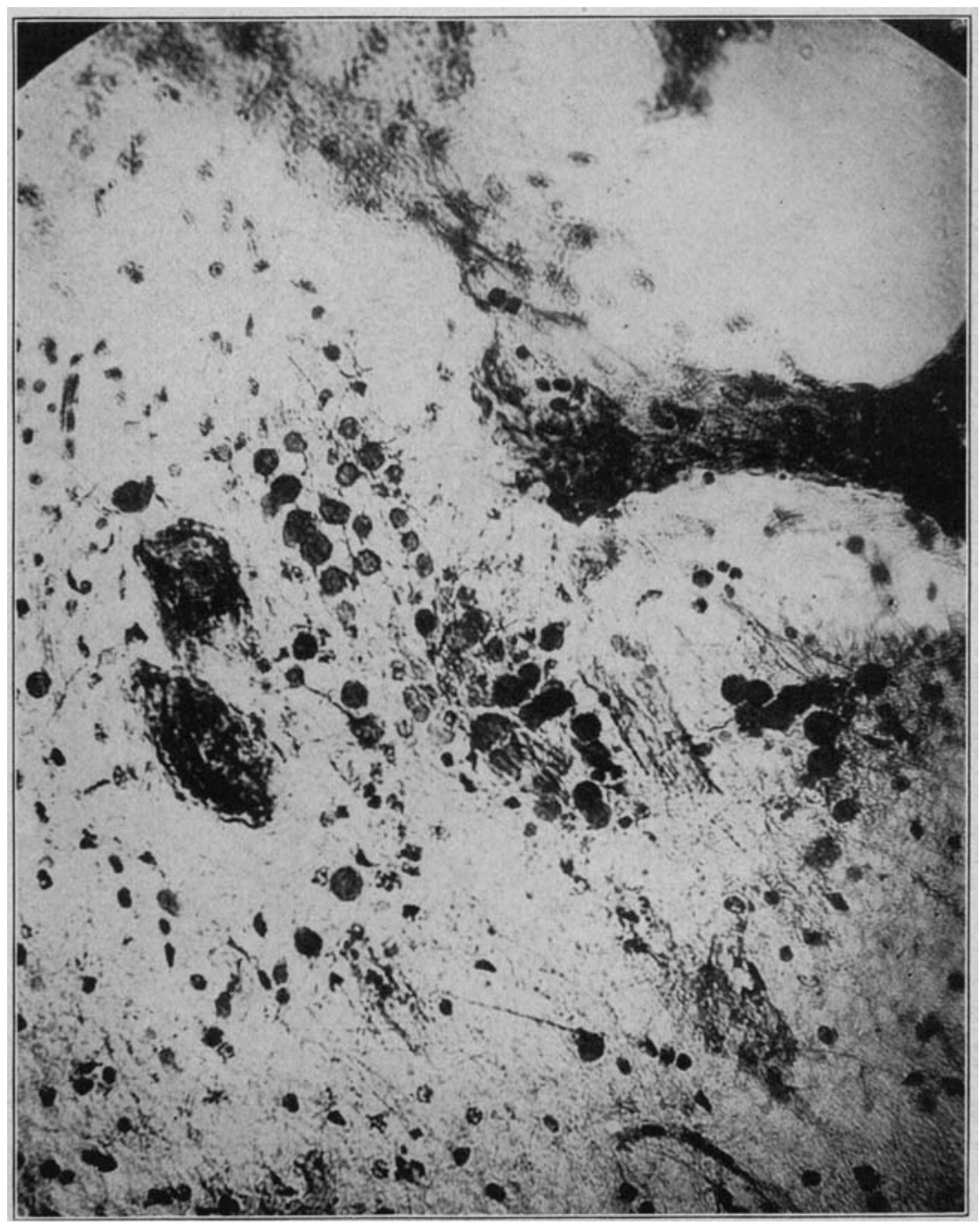

Fig. 10.-Enlarged picture from section of Figure 8.

arteriosclerotic alteration is focal in character, whereas senile changes show diffuse distribution." So the second group of changes is different from those of an arteriosclerotic nature and resembles more the normal senile alteration. 
We have, then, a case showing the combination of arteriosclerosis and senile changes. Now the question is: Are these arteriosclerotic alterations with senile changes due to the myxedema, or are they independent of it? The patient was 66 years old, and it is quite pos: sible to show arteriosclerotic alterations and even senile changes without anv disturbance of the internal secretion. But one thing should be mentioned - the fatty degeneration of the ganglion cells is too great for the normal senile changes at this age, and that makes the question much more complicated.

It is, however, a common occurrence in senility for the thyroid to become atrophic and undergo diffuse sclerosis, destroying the gland tissue. Horsley declares that old age is only a form of mitigated hypothyroidism, and that the people who enjoy a green old age owe this happy condition to a thyroid which has remained normal. "The points of resemblance," says Crotti," "between senility and a slight degree of hypothyroidism are more than one. Falling out of the hair, deafness, falling of the teeth, dryness of the skin, arteriosclerosis. bradycardia, diminution of the function of the nervous system and other symptoms which occur both in old people and hypothyroidism, can all be attributed to the atrophic condition of the thyroid gland." If this hypothesis is true, the question is very much simplified. For the increased arteriosclerosis and senile changes are nothing but the manifestation of the diminished function of the thyroid gland, and the pathologic findings which have been observed can safely be attributed to the hypothyroidism.

Schnitzler ${ }^{10}$ described a case of a 32-year-old female, who had shown marked clinical symptoms of myxedema and mental symptoms of apathy and stupor and somnolence. He grouped his case with the type of which Spielmeyer wrote as "causes of senile dementia which differ from the usual type in that the marked dementia rapidly ensues, together with focal symptoms of asymbolic and aphasic character." He shows, however, as Fuller expressed it, an inclination to flirt with the rather fascinating idea of an origin from disordered internal secretions, since his case and one of the cases reported by Perusini exhibited certain myxedematous symptoms. "Although," Schnitzler says, "the thyroid gland could not be examined postmortem, since the patient became very much better under the administration of thyroid preparation, it is quite possible that we dealt with a thyrogeneous disease. So we have a case, showing a possibility of an intimate relationship between internal secretion and senile degeneration. If the normal

9. Grotti: Thyroid and Thymus, Philadelphia, Lea \& Febiger, 1918.

10. Schnitzler: Zur Alogrenzung der sogenannten Alzheimerschen Krankheit. Ztschr. f. d. ges. Neurol. u. Psychiat. 7:34, 1911. 
senile degeneration is merely a consequence of hypofunction of the thyroid gland, can this condition of senile changes in our case not be attributed to the complication of the myxedema?" It seems to me rather unnatural to have classed his case as senile dementia. I see no reason why it should not be grouped with the myxedematous psychoses. In his case he has found no senile plaques; he has observed Alzheimer's neurofibrillar change, but this is not at all pathognomonic of senile dementia or of other senile conditions. Goto ${ }^{11}$ found typical Alzheimer's ${ }^{12}$ change in feebleminded subjects, and even in dementia precox. I was unable to find any of these changes in any parts of the brain in this case.

Further, if we look over the mental symptoms, such as loss of memory, especially for recent events, disturbance of the attention, suspiciousness, acute dementia, etc., which are always found in senile cases as well as in this case, we cannot believe that the anatomic substrata of this disease is dependent on anything else than the senile changes in a broad sense - i. e., arteriosclerotic alterations, normal senile alterations and characteristic degeneration of senile dementia.

As for the cell change associated with the edematous condition, though it has, of course, nothing to do with senility, it must be considered as pathognomonic, since the edematous condition itself is the partial manifestation of the general symptoms of this disease.

The cerebellum was found more intensively degenerated than the cerebrum. The Purkinje cells diminished in number, those remaining showing marked degeneration. The fatty degeneration of the Purkinje cells, however, was not so marked as of the ganglion cells of the brain and the spinal cord which shows merely that the Purkinje cells are so-called lipophobic cells and nearly always escape fatty degeneration.

How far the cerebellar symptoms of reported cases and of the present case can be attributed to the pathologic anatomic conditions of the cerebellum is hard to answer, but it is quite probable that they have played more or less of a part in the existence of such marked symptoms.

\section{SU M MARY}

1. The writer presents a case of typical myxedematous psychosis which showed, together with known symptoms, marked disturbance of coordination, vertigo and somnolence.

11. Goto: Alzheimersche Neurofibrillenveraenderungen in der Hirnrinde der Schwachsinnigen, Tokio Shinkeigakkai Zasshi, 1917.

12. Alzhemer: Die arteriosklerotische Atrophie des Gehirns, Allg. Ztschr. f. Psychiat. 51:809, 1895. Beitrag zur pathologische Anatomie der Seelenstoerungen des Greisenalters, Neurol. Centralbl. 18:95, 1899. Seelenstoerungen anf arteriosklerotischer Grundlage, Allg. Ztschr. f. Psychiat 59:695, 1902. 
2. The thyroid gland was found extremely atrophic with the gland tissue replaced by connective tissue fibers and with no isthmus. The remaining gland tissue was infiltrated by lymphatic cells. The writer suspects some etiologic relationship between the congenital factor and this disease.

3. The pituitary body was smaller than normal, though microscopically there was no evidence of atrophy.

4. The right ovary was removed ten years ago, the left remained atrophic, showing an evidence of chronic inflammatory process.

5. The writer suspects, having seen a similar condition of ovaries in a former case of the Danvers State Hospital series, some etiologic factors in certain diseased conditions of the ovaries.

6. The pathologic changes in the brain and the cerebellum consist of arteriosclerotic alterations, general senile changes and cell change associated with the edematous condition.

7. The writer attributes the arteriosclerotic alterations and the general senile changes to the effect of the myxedematous disease.

8. The cell change associated with the edematous condition is considered as pathognomonic.

The writer believes also that there is a possible correlation between the marked atrophy of the cerebellum and the clinical symptoms of disturbed coordination and of vertigo.

The writer is indebted to the staff of the Danvers State Hospital, especially to Drs. Macdonald, Bryan and Stevenson, for completing this report. He is also indebted to Drs. Southard and Canavan for their encouragement and advice in his study. To all of these he wishes to express his appreciation.

In addition to the references already given, the following will be found of interest:

Barham, G. F.: Insanity with Myxedema, J. Ment. Sc. 58:226, 1912.

Alzheimer: Ueber eine eigenartige Erkrankung der Hirnrinde, Allg. Ztschr. f. Psychiat. 64: 146, 1907. 